\title{
RETHINKING FINANCIAL REWARDS FOR WHISTLE- BLOWERS UNDER THE PROPOSAL FOR A DIRECTIVE ON THE PROTECTION OF WHISTLE-BLOWERS REPORTING BREACHES OF EU LAW
}

\author{
DIMITRIOS KAFTERANIS*
}

\begin{abstract}
The European Commission recently published a proposal for a Directive on the protection of whistle-blowers reporting breaches of EU law. This proposal is welcomed not only by the legal community but also by many citizens who desire more transparency. The recent scandals revealed by whistle-blowers along with the active role of the European Parliament have led the European Commission to propose this important text of the proposed Directive. The whistle-blower is recognised as an enforcement tool for the EU and is a key component in helping to ensure the successful enforcement of EU law. There is one element, however, that is not discussed by the European Commission: financial rewards for the whistle-blowers. ${ }^{1}$ The United States, especially in the financial sector, has adopted a system of financial awards. Europe, on the other hand, is resistant to introducing such incentives. The aim of this paper is to introduce the proposal for a Directive and to highlight the problems that such a step may create at the EU level.
\end{abstract}

\section{INTRODUCTION: WHISTLE-BLOWERS AND THE FINANCIAL CRISIS}

The major financial crises of recent years have demonstrated the failure of enforcement of the rules governing the financial sector and also the lack of detecting misconduct in the banking and financial sector. ${ }^{2}$ Whistle-blowing gained much attention, firstly in the US and then in Europe following the stock market crash of 2002 and became a topical issue for governments, regulators and scholars. The adoption of different pieces of legislation in the US and Europe demonstrate this attention. ${ }^{3}$ Scandals such as ENRON and WORLDCOM, could have had different consequences if the employees' concerns about their opaque practices and their accounting situation were heard and treated properly. ${ }^{4}$ These events have

\footnotetext{
* PhD researcher at the Faculty of Law at the University of Luxembourg. Supported by the Luxembourg National Research Fund (FNR) - 10965388/ Soutenu par le Fonds National de la Recherche, Luxembourg (FNR) - 10965388. Contact: dimitrios.kafternais@uni.lu

${ }^{1}$ The European Commission considers financial rewards in the annex of the impact assessment of the proposal for a directive but it does not entail it in the main text of the proposed Directive.

${ }^{2}$ Michael Neal, 'Securities Whistleblowing under Dodd-Frank: Neglecting the Power of "Enterprising Privateers" in Favor of the "Slow-Going Public Vessel" (2012) 15 Lewis \& Clark Law Review 1124-1126 where he analyses what happened with ENRON, WorldCom and their employees who were raising concerns. ${ }^{3}$ See to that extent the adoption of Sarbanes-Oxley Act (2002) and the Dodd-Frank Act (2010) by the US and the Protected Disclosures Act (2014) in Ireland and the Law Sapin II (2016) in France.

${ }^{4}$ Ian A. Engoron, 'A Novel Approach to Defining “Whistleblower" in Dodd-Frank' (2017) (23(1) Fordham Journal of Corporate and Financial Law, 265. Apart from ENRON and WORLDCOM that occurred in the US, Europe also had its own scandals such as Panama Papers or Paradise Papers that implicated European citizens and countries in tax evasion and money laundering.
} 
led the US government to react by enacting legislation in order to assure the safety and soundness of the financial sector. ${ }^{5}$ The first piece of legislation was the Sarbanes-Oxley Act of 2002 that entailed provisions for whistle-blowing. ${ }^{6}$ Along with this Act and following the crisis of 2008, the Dodd-Frank Act of 2010 was signed by President Obama in an effort to strengthen the rules for the financial sector. ${ }^{7}$

The Dodd-Frank Act adopted a robust system of whistle-blowing protection allowing the Securities and Exchange Commission (SEC) to offer financial rewards to whistle-blowers under certain circumstances. ${ }^{8}$ The bounty programme of the Dodd-Frank Act has received attention from the legal and political world as many praised the fact that it allowed for successful claims to be brought to the SEC and for the whistle-blower to be rewarded. ${ }^{9}$ It should be noted, though, that financial rewards for whistle-blowers is not a new phenomenon for the US and the financial awards systems dates back to the False Claims Act, adopted in $1863 .{ }^{10}$

Unlike the US context, the protection of whistle-blowers in European countries is incoherent. ${ }^{11}$ Cultural, social and political concerns were an obstacle for most of the European countries in relation to the adoption of comprehensive whistle-blowing legislation. ${ }^{12}$ The most important step was the recent proposal for a Directive of the European Commission on the protection of whistle-blowers reporting breaches of European law. ${ }^{13}$ The text is assuring and inspiring, criticised though for its lack of specific reference to financial rewards for whistle-blowers. ${ }^{14}$ The present contribution presents a particular interest due to the recent developments in the US case-law alongside the draft proposal for a Directive on the protection on the whistle-blowers. In addition, the existing legal literature on this issue, at the EU level, is not abundant and the previous texts are outdated.

${ }^{5}$ Samuel C. Leifer, 'Protecting Whistleblower Protections in the Dodd-Frank Act' (2014) 113 Michigan Law Review, 121, 125-129.

${ }^{6}$ Sarbanes-Oxley Act 2002, Washington D.C., U.S. G.P.O., 2002.

${ }^{7}$ Dodd-Frank Wall Street Reform and Consumer Protection Act, Pub. L. No. 111-203, \929-Z, 124 Stat. 1376, 1871 (2010) (codified at 15 U.S.C. S 78o) [Bluebook R. 12.4].

${ }^{8}$ Dodd-Frank Wall Street Reform and Consumer Protection Act (Dodd-Frank Act), Pub. L. No. 111-203, \$§748, 922, 124 Stat. 1380, 1381 (2010) (codified in 15 U.S.C. \ 78n (2012)).

9 Christina Parajon Skinner, 'Whistleblowers and Financial Innovation' (2016) 94 North Carolina Law Review 861,861 .

${ }^{10}$ Michael Neal, 'Securities Whistleblowing under Dodd-Frank: Neglecting the Power of "Enterprising Privateers" in Favor of the "Slow-Going Public Vessel"” (2012) 15 Lewis \& Clark Law Review 1110-1116 where the False Claims Act along with the IRS whistle-blower program are discussed in detail.

${ }^{11}$ European Commission, Commission Staff Working Document, Impact Assessment accompanying the document of the proposal for a Directive of the European Parliament and of the Council on the protection of persons reporting on breaches of Union law $\operatorname{COM}(2018) 218$ final, available on: $<$ https://eur-

lex.europa.eu/legal-content/EN/TXT/PDF/?uri=CELEX:52018SC0116\&from=EN $>$ accessed on 30 October 2018, 3 .

12 European Commission, Impact Assessment (n 11) 14.

${ }^{13}$ European Commission, Proposal for a directive of the European Parliament and of the Council on the protection of persons reporting breaches of Union law $\operatorname{COM}(2018) 218$ final, available on : < https://ec.europa.eu/info/sites/info/files/placeholder 8.pdf $>$ accessed on 10 May 2018.

${ }^{14}$ Theo Nyreröd \& Giancarlo Spagnolo, 'Myths and Numbers on Whistleblowing' (2018) Working Paper $\mathrm{n}^{\circ}$ 44, Stockholm Institute of Transition

Economics<https://papers.ssrn.com/sol3/papers.cfm?abstract_id=3100754 > and see also from the same authors : 'A proposed EU directive on whistle-blower protection' (2018)

$<$ https://voxeu.org/article/proposed-eu-directive-whistleblower-protection $>$. 
The article is structured as follows: In the first part, the situation at the EU level will be presented and the reasons for not adopting financial rewards. In the second part, the aim is to present briefly the bounty programme of the SEC and the implications following the United States Supreme Court decision in Digital Realty Trust, Inc v. Somers for internal whistleblowing. ${ }^{15}$ Before concluding, the intention is to present some alternative suggestions instead of financial rewards for the future whistle-blowers. The conclusions will recap on the arguments laid out in this article.

\section{THE EUROPEAN PERSPECTIVE}

The European Commission on April 2018 presented its proposal for a Directive on the protection of whistle-blowers reporting breaches of EU law. ${ }^{16}$ This proposal for a Directive came after the pressure of the European Parliament to protect whistle-blowers at the EU level. Scandals such as Luxleaks or Panama Papers have influenced the European Parliament which became an advocate working in favour of the protection of whistle-blowers. ${ }^{17}$ The text of the proposed Directive of the European Commission complies with the international standards in this field. ${ }^{18}$ The Commission regards whistle-blowing as an enforcement tool for the European legislation. One of the reasons for proposing the Directive is to ensure the stability of financial markets, the balance of EU economies and their fair competition. ${ }^{19}$

The proposal for the Directive, presented by the European Commission on April 2018 , is an important text towards an effective protection of the whistle-blowers. ${ }^{20}$ The text adopts many of the international standards, in the field, notably the texts of the Council of Europe and the case-law of the European Court of Human Rights. ${ }^{21}$ The proposed definition of the whistle-blower is large in an effort to protect people's different types of reporting. ${ }^{22}$ The procedural aspect is similar to the one adopted by the European Court of Human Rights in its landmark case Guja v. Moldova. ${ }^{23}$ The three-tier model is proposed where the whistleblower should report internally first, to the authorities, as a second step if the internal reporting is not responding, and as a last resort to the public (media). ${ }^{24}$ The protection of the

\footnotetext{
${ }^{15}$ Digital Realty Trust, Inc. v Somers, 138 S. Ct. 767 (2018).

${ }^{16}$ European Commission, Proposal for a directive (n 13).

${ }^{17}$ European Parliament Resolution of 24 October 2017 on legitimate measures to protect whistle-blowers acting in the public interest when disclosing the confidential information of companies and public bodies $(2016 / 2224(\mathrm{INI}))<$

http:/ / www.europarl.europa.eu/sides/getDoc.do?type=TA\&language=EN\&reference=P8-TA-2017-0402>.

${ }^{18}$ Some examples of international standards considered, inter alia, are the following:

G20 Anti-Corruption Action Plan, Protection of whistleblowers - Study on whistleblower protection

frameworks, compendium of best practices and guiding principles for legislation $(2012)<$

https://www.oecd.org/g20/topics/anti-corruption/48972967.pdf>. In pg. 32 of the Study, one proposed

measure is the possibility of financial rewards for whistle-blowing.

Council of Europe, Recommendation CM/Rec(2014)7, Protection of whistle-blowers, adopted by the

Committee of Ministers, 30 April 2014 (where there is no reference to financial rewards).

${ }^{19}$ European Commission, Impact Assessment (n 11) 12.

${ }^{20}$ European Commission, Proposal for a directive (n 13).

21 ibid., 10.

22 ibid., 18.

${ }^{23}$ Guja v. Moldova App no 14277/04 (ECtHR 12 February 2008).

${ }^{24}$ European Commission, Proposal for a directive (n 13) 20-24.
} 
whistle-blowers is large too, where the whistle-blower is protected in terms of labour, civil and criminal law. ${ }^{25}$

Although the significance of the text, different issues arise in relation to some of its points. One issue is the material scope of the proposed Directive as it is considered that it tries to cover many different areas of EU law, leaving in addition the opportunity to the Member States to enlarge the scope even more which in the end, may create a complexity that may impede whistle-blowing. ${ }^{26}$ Furthermore, the fact that the European Commission exempts certain public and private entities from introducing internal reporting structures would be an obstacle to the effective protection of whistle-blowers. ${ }^{27}$ Another issue, which is in the interest of this article, is the question of financial rewards for whistle-blowers where a different approach is followed by the US financial authorities and is worthy being analysed in relation to the European perspective.

Although analysing in more details the text would be an interesting exercise, the focus in this paper is on the question of financial rewards. The European Commission discussed the issue in the appendix of the impact assessment accompanying the proposal for the Directive but it did not include it in the main body of the proposed text of the Directive. ${ }^{28}$ It is likely that it preferred not to address this issue directly in the proposed text of the Directive as no European country had heretofore put in place such a mechanism. On July 2014, the Financial Conduct Authority of the United Kingdom in a note it published, defended its position not to adopt financial rewards for whistle-blowers. ${ }^{29}$ In its reasoning it highlighted that enacting financial incentives for the whistle-blowers could undermine the effective internal whistle-blowing mechanisms - on top of being costly and complex for the financial authorities to administer, and rewarding only a small number of whistle-blowers (only those who are successful). ${ }^{30}$

Interestingly the European Commission in its EU Market Abuse Regulation has provided the possibility for Member States to offer financial incentives to persons that offer information for infringements of the Regulation. ${ }^{31}$ Article 32(4) reads:

Member States may provide for financial incentives to persons who offer relevant information about potential infringements of this Regulation to be granted in accordance with national law where such persons do not have other pre-existing

\footnotetext{
25 ibid., 27-28.

${ }^{26}$ European Court of Auditors, Opinion No 4/2018 concerning the proposal for a Directive of the European Parliament and of the Council on the protection of persons reporting on breaches of Union law, available on : < https://www.eca.europa.eu/Lists/ECADocuments/OP18 04/OP18 04 EN.pdf $>$ accessed on 30 October 2018, 6 .

27 ibid., 8.

${ }^{28}$ European Commission, Impact Assessment (n 11) 36, where the European Commission states that: ä 'Member States retain the possibility to apply further measures to facilitate or encourage whistleblowing, which go beyond the core standards promoted by the ECtHR/CoE, such as rewards'.

${ }^{29}$ Financial Conduct Authority \& Prudential Regulation Authority for the Treasury Committee, Note for financial incentives for whistleblowers (2014) available on: < https://www.fca.org.uk/publication/financialincentives-for-whistleblowers.pdf $>$ accessed on 29 September 2018.

30 ibid., 2-3.

${ }^{31}$ Insley Holly, 'Whistleblowing in the financial services sector - does motive matter ?' (Freshfields Bruckhaus Deringer 2017)< http://risk.freshfields.com/post/102eguw/whistleblowing-in-the-financialservices-sector-does-motive-matter $>$.
} 
legal or contractual duties to report such information, and provided that the information is new, and that it results in the imposition of an administrative or criminal sanction, or the taking of another administrative measure, for an infringement of this Regulation. ${ }^{32}$

The European Commission, in its explanatory memorandum for the proposed regulation, highlighted the importance of introducing whistle-blowing mechanisms which will help the relevant authorities to have more information about suspected market abuse. ${ }^{33}$ To that end, it allowed the use of financial incentives in order to incentivise more employees to reveal breaches of the Market Abuse Regulation.

Despite these efforts, it seems that no member state has opted for financial rewards. ${ }^{34}$ European countries were already reluctant to adopt legislation on the protection of whistleblowers and consequently more reluctant to the idea of financial rewards. ${ }^{35}$ The United Kingdom was among the first to adopt whistleblower protection legislation in 1998 but it still rejects the idea of enacting a bounty programme within the financial markets. ${ }^{36} \mathrm{Whistle-}$ blowing is viewed differently in the US and Europe. There are cultural differences that should draw our attention. ${ }^{37}$ The EU countries would like to ensure the effective relationship of employer and employee and this is mirrored in the adopted legislation at the European level. ${ }^{38}$ Common law countries such as Ireland and the United Kingdom mandate internal reporting as a first step for the whistle-blower. ${ }^{39}$ To the same direction, the recent French legislation on whistle-blowing requires clearly that the whistle-blower reports internally in order to avail himself of the offered protection. ${ }^{40}$

In the US media, whistle-blowers have been named 'Persons of the Year' in 2002 whereas in Europe there is still some suspicion towards those described as whistleblowers. ${ }^{41}$ German society illustrates this suspicion due to strong feelings of aversion resulting from the denunciation practice under the Nazi regime. ${ }^{42}$ The same aversion goes for Central and Eastern post-communist EU member states. It is likely that, under the influence of the US legislation for the financial markets and the recent scandals revealed by whistle-blowers, a more positive atmosphere is being created in Europe.

The United Kingdom is an example of where this shift in attitude took place following the introduction of legislation regarding whistle-blowers. Prior to the enactment of the Public

\footnotetext{
32 Regulation (EU) N N $^{\circ 96 / 2014}$ of the European Parliament and of the Council of 16 April 2014 on market abuse (market abuse regulation), O.J.E.U. L 173/1.

${ }^{33}$ Explanatory Memorandum of the Proposal for a Regulation on marker abuse at pg. 15.

${ }^{34}$ Nyreröd \&Spagnolo (n 14) 7.

35 European Commission, Impact Assessment (n 11) 36.

${ }^{36}$ Financial Conduct Authority (n 29).

${ }^{37}$ Terry Morehead Dworkin, 'SOX and Whistleblowing' (2007) Michigan Law Review, vol. 105, issue 8, 1774.

${ }^{38}$ See to that extent the English, Irish and French legislation on whistle-blowing where both countries are incentivising internal reporting as the first step the whistle-blower should follow.

${ }^{39}$ Public Interest Disclosure Act 1998, Section 43C and Protected Disclosures Act 2014, number 14 of 2014, Ireland, part 2, paragraph 6.

${ }^{40}$ Law n ${ }^{\circ} 2016-1691$ of 6 December 2016 related to transparency, the fight against corruption and the modernization of economic life, JORF $\mathrm{n}^{\circ} 0287 \mathrm{art} .8$.

41 Time Magazine, December 2002, pictures of Cynthia Cooper (WorldCom), Coleen Rowley (FBI) and Sharren Watkins (Enron).

${ }^{42}$ Mark Worth, Whistleblowing in Europe 15-16, 47-48 (2013).
} 
Interest Disclosure Act 1998, whistle-blowing had a negative connotation and the media were not in its favour. The adoption of the Act changed this negative perception of reporting wrongdoings and now twenty years later, the picture has changed. ${ }^{43}$ The recent case of the Barclays chief executive Jes Staley, illustrates the new attitude towards whistle-blowing. Jes Staley tried to unmask a whistle-blower and the Financial Conduct Authority fined him $£ 642,000$ sterling over this scandal. ${ }^{44}$ The whistle-blower is not considered an industrial troublemaker but a concerned citizen who wants to report a wrongdoing and rectify it. ${ }^{45}$

Moreover, there are fears that the enactment of a financial rewards scheme will undermine the efforts of internal reporting structures. As it will be discussed later, those fears came true following the decision of the Supreme Court in Digital Realty Trust, Inc v Somers in the US. ${ }^{46}$ If authorities put in place financial rewards, the worker could be tempted to report directly to them. In this scenario, the internal compliance structures will be powerless and companies will face problems in relation to the loyalty of their employees. Reporting internally is a sign of the employee's loyalty to the company and trust that the wrongdoing will be rectified. ${ }^{47}$

Apart from the possible undermining of internal reporting structures, financial rewards, in the EU level, would be in conflict with the case law of the European Court of Human Rights. The Strasbourg Court has noted in many reprisals, that whistle-blowing which is 'motivated by a personal grievance or a personal antagonism or the expectation of personal advantage, including pecuniary gain, would not justify a particular level of protection $^{38}$. In addition, the introduction of financial rewards will shift the aim of whistleblowing away from the public interest, which is an important factor for the European Court of Human Rights and for the proposal of the European Commission for a Directive, to a personal pecuniary scope where reporting will be seen more as a commercial transaction than as an act towards the protection of the public interest. ${ }^{49}$

Taking into account the scenario where the European Commission will ask Member States to provide for financial incentives when reporting breaches of European law, the reality could prove complex. Would allowing macro level authorities, such as the European Central Bank (ECB) or the European Securities and Markets Authority (ESMA), to provide financial rewards to influence public attitudes in relation to the value of whistle-blowing be

\footnotetext{
${ }^{43}$ James Gobert \& Maurice Punch, 'Whistleblowers, the Public Interest, and the Public Interest Disclosure Act 1998' (2003) The Modern Law Review, vol. 63, issue 1, 54.

${ }^{44}$ Nick Fletcher, 'Barclays boss Jes Staley fined $f_{6} 642,000$ over whistleblower scandal' The Guardian (11 May 2018) < https://www.theguardian.com/business/2018/may/11/barclays-jes-staley-fined-whistleblower-fca> . ${ }^{45}$ Gobert \&Punch (n 43) 54.

${ }^{46}$ See section $C$ about US.

47 Bornfelt P-O, Arvidson Markus, Axelsson Jonas \& Ahlstrand Roland, 'Whistle-blowing in the light of loyalty and transparency' (2014) Paper to the 7th Nordic Working Life Conference, Goteborg, Sweden, 1-2. 48 Guja v. Moldova App no 14277/04 (ECtHR 12 February 2008), \$77.

This point was, also, raised by the European Commission in the appendix of the impact assessment related to the proposal for a directive on the protection of whistle-blowers at page 36-37.

${ }^{49}$ European Commission, Impact Assessment (n 13) 36.
} 
the correct approach? Both agencies, ECB and ESMA, provide whistle-blowing reporting lines but there is little information available on their practices ${ }^{50}$ In addition, the legal instrument that the European Commission has chosen for the protection of whistle-blowers is a Directive. ${ }^{51}$ The Directive will set minimum standards that every Member State has to follow, although some jurisdictions may choose to include additional requirements. In the event of a bounty programme, the Directive will set a standard. The Member States will have the discretion as to the form and methods for its implementation. ${ }^{52}$ This fact could plausibly create the following situation: every Member State would have different rewards in place. Thus, it may induce forum-shopping behaviour as if there are two or more countries involved, the employee may understandably try to report to the country that offers the best incentive. $^{53}$

\section{THE US PERSPECTIVE ON FINANCIAL REWARDS}

The Anglo-Saxon legal tradition is keen on allowing private citizens to aid the enforcement mechanisms of the State for certain matters. The most relevant example is the use of qui tam writ that authorises citizens to sue someone if the interests of the State are not respected. ${ }^{54}$ The qui tam writ served as the basis for the enactment of the US False Claims Act that had to deal with fraud against the US government during the Civil War and it allowed individuals to bring lawsuits on behalf of the State. ${ }^{55}$ In addition, the Internal Revenue Service pays rewards to whistle-blowers when they provide information related to tax concerns. ${ }^{56}$ All the above demonstrate that the US legislature is keen on allowing private parties to participate to facilitate the enforcement of US regulations. This became apparent, also, with the enactment of Dodd-Frank and more particularly with its bounty programme.

The modern financial sector is innovative and complex. These characteristics pose particular challenges on the law enforcement agencies. It is common that regulators may lack expertise in certain areas of the financial sector and consequently the detection of misconduct may become more challenging for them. ${ }^{57}$ The stock market crash of 2002 and the financial crisis of 2008 has led the United States to react in order to ensure the safeness and soundness of

\footnotetext{
${ }^{50}$ European Central Bank, Feedback on the input provided by the European Parliament as part of its resolution on the ECB Annual Report for 2016 at 10 where the ECB was laconic concerning its internal whistle-blowing policies.

51 Art. 288 of the Treaty on the Functioning of the European Union (2016) OJ C 202.

Damian Chalmers, Gareth Davies \& Giorgio Monti, European Union Law, (CUP 2 $2^{\text {nd }}$ edn., 2010) 99.

52 ibid., 99.

${ }^{53}$ Skinner (n 9) 911 (explaining the unilateral extraterritorialism).

${ }^{54}$ David Freeman Engstrom, 'Harnessing the Private Attorney General: Evidence from Qui Tam Litigation' (2012) 112 Columbia Law Review 1244, 1246.

${ }^{55}$ False Claims Act (FCA), 31 U.S.C. \$S 3729-3733. A suit filed by an individual on behalf of the government is known as a "qui tam" action, and the person bringing the action is referred to as a "relator". For more information about the FCA : < https://www.justice.gov/sites/default/files/civil/legacy/2011/04/22/CFRAUDS FCA Primer.pdf $>$.

Michael Neal, 'Securities Whistleblowing under Dodd-Frank : Neglecting the Power of "Enterprising Privateers" in Favor of the "Slow-Going Public Vessel”" (2012) Lewis \& Clark Law Review, vol. 15:4, 1110. 56 Yehonatan Givati, 'Of Snitches And Riches: Optimal IRS and SEC Whistleblower rewards' (2018) Harvard Journal on Legislation, vol. 55, 112.

${ }^{57}$ Skinner (n 9) 867.
} 
the financial markets. ${ }^{58}$ When Enron and WorldCom collapsed and the stock market crashed in 2002, the US Congress passed the Sarbanes-Oxley Act where there is a reliance on whistleblowers. ${ }^{59}$ Despite this reliance, the Sarbanes-Oxley Act had no provisions for financial rewards. The Sarbanes-Oxley Act did not have the anticipated success and just six years later, the financial crisis of 2008 arrived with disastrous consequences for the world's economies. ${ }^{60}$ The US reaction was the Dodd-Frank Act signed by President Obama in order to promote 'the financial stability of the United States by improving accountability and transparency in the financial system, to end 'too big to fail', to protect the American taxpayer by ending bailouts, and to protect consumers from abusive financial services practices' ${ }^{61}$ Section (b) of the Act provides the possibility to the SEC to grant financial rewards to whistle-blowers in accordance with the Act. ${ }^{62}$

Despite the merits of the policy of private enforcement through financial rewards, businesses and academics raised concerns about this practice. One of the most important concerns about the financial rewards is the undermining of internal compliance. The definition of compliance as it was given by the Basel Committee in its Consultative document on the compliance function in banks is the following:

An independent function that identifies, assesses, advises on, monitors and reports on the bank's compliance risk, that is, the risk of legal or regulatory sanctions, financial loss, or loss to reputation a bank may suffer as a result of its failure to comply with all applicable law, regulations, codes of conduct and standards of good practice. $^{63}$

The concern is that the financial rewards offered by the SEC, under Dodd-Frank, will discourage employees from reporting internally as they will have more benefits if they report successfully externally, thereby undermining the role of corporate compliance.

The recent decision of the US Supreme Court in Digital Realty Trust, Inc v. Somers had hardened the path for internal whistle-blowing. This fear became a reality for the corporate world following the decision of the Supreme Court in the case Digital Realty Trust, Inc v. Somers. ${ }^{64}$ The problem hinges on the definition of the whistle-blower. ${ }^{65}$ In a nutshell, the debate was if, under the Dodd-Frank Act, the definition of the whistle-blower entails those that report internally and not to the SEC. ${ }^{66}$ Prior to the decision of the Supreme Court, there

\footnotetext{
58 Engoron (n 4) 265-268.

5918 U.S.C. (2002) s. 806

Terry M Dworkin, 'SOX and Whistleblowing' (2007) 105 Michigan Law Review 1757, 1757.

${ }^{60}$ The Sarbanes-Oxley Act failed as, for more than a decade, did not sufficiently protect whistle-blowers suffering retaliation and despite the legal protection offered by the Act, whistle-blowers did not play an important role in uncovering the financial crisis of 2008. See to that extent: Richard Moberly, 'SarbanesOxley's whistleblower provisions: ten years later' (2012) 64 South Carolina Law Review 1.

${ }^{61}$ Dodd-Frank Wall Street Reform and Consumer Protection Act, Pub. L. No. 111-203, 124 Sta. 1376 (2010)

6215 U.S.C. $\int 78 \mathrm{u}-6(\mathrm{~b})(1)$.

${ }^{63}$ Basel Committee on Banking Supervision, Consultative Document, The Compliance Function in Banks, $\$ 10,2003$.

${ }^{64}$ Digital Realty Trust, Inc. v Somers, 138 S. Ct. 767 (2018).

${ }^{65}$ Engoron (n 4) 275.

${ }^{66}$ Digital Realty Trust, Inc. v. Somers, 138 S. Ct. 767, 773(2018).
} 
was a dichotomy among US Courts on this issue. ${ }^{67}$ The Supreme Court decided that the wording of the Dodd-Frank Act recognises a whistle-blower only as an employee who reports to the SEC. ${ }^{68}$ This employee is entitled to the anti-retaliation protections offered by the Dodd-Frank Act. Even though the case was brought by the employer of Mr. Somers, it actually turned against him at the end. The Supreme Court favoured the employee being sued, but at the same time it gave a robust consternation to internal compliance programmes.

The authorities may in turn face more reporting from employees. This fact is not negative at first blush, but it may become overwhelming for the investigative authorities if the volumes of reports increase and indeed if some of these reports are of a frivolous nature. The cash-incentivised programme leaves space for speculation from employees that hope to be awarded an amount of money. Therefore, more employees may be encouraged to report to the SEC and more resources will be needed to investigate all these concerns. Under these circumstances, the idea of private enforcement may place a burden on reporting systems utilised by the authorities and the State. ${ }^{69}$

The financial rewards for whistle-blowers can also have implications for social cohesion and relationships in any given society. Even in the open-minded US societies, whistle-blowers are not always considered as an ethical choice and may have negative connotations. ${ }^{70}$ The bounty programmes are seen as a sign of limiting corporate loyalty. Encouraging whistle-blowing especially with the possibility of a financial reward may be considered as an enemy of business. ${ }^{71}$ The Supreme Court decision is more alarming for the business sector as the State provides an incentive for the whistle-blower to report directly to the SEC and not internally if he desires to be protected under the auspices of Dodd-Frank. However, in the author's view, these anti-social concerns may be outweighed by the social cost of not detecting financial misconduct.

\section{ALTERNATIVES TO FINANCIAL REWARDS}

The purpose until now was to present the issue of financial rewards in the U.S. and in the EU and to explore the challenges it presents to the EU financial markets. The text of the proposed Directive is an inspiring text that complies with most of the international standards on whistle-blowing. However, there is no provision in it for financial rewards. The spirit of the proposed text is to enhance internal reporting and subsequently reporting to the authorities. Before concluding, it would be useful to propose some alternatives to financial rewards for whistle-blowers. Those alternatives are the promotion of an effective internal whistle-blowing system, of a new model of business education and, last but not least, an international cooperation on whistle-blowing. Those alternatives may positively enhance whistle-blowing without adopting financial rewards.

\footnotetext{
${ }^{67}$ Asadi v. G.E. Energy (USA), LLC 720 F.3d 620 (5th Cir. 2013).

Berman v. Neo@Ogilvy 801 F.3d 145 (2d Cir. 2015).

${ }^{68}$ Digital Realty Trust, Inc. v. Somers, 138 S. Ct. 767, 777 (2018).

${ }^{69}$ Dennis J. Ventry, Jr., 'Digital Realty Trust, Inc. v. Somers: Bad News for Employers, Lawyers and Internal

Compliance' (2018) JURIST - Academic Commentary< http://jurist.org/forum/2018/02/dennis-j-ventryir-digital-realty-trust-bad-news.php>.

${ }^{70}$ Ethan Brown, Snitch: informants, cooperators \& the corruption of justice (PublicAffairs 2007)

${ }^{71}$ Kenneth D. Walters, 'Your Employees' Right to Blow the Whistle' (1975) Harvard Business Review 26-27.
} 
The adopted legislation will incite whistle-blowers to report internally before addressing their concerns to authorities. Corporations should develop a correct and effective internal reporting mechanism. This will enhance corporate culture and governance as the business recognises an important place for its employees on the good functioning of the corporation. ${ }^{72}$ In practice, the corporation should recognise as 'mission-critical' that every corporate compliance department and every individual has rights and responsibilities in relation to whistle-blowing. ${ }^{73}$ The creation of such an atmosphere for the internal reporting may diminish the need for financial rewards and reporting to the authorities. Nevertheless, employees would still be able to report to the authorities if the internal reporting system did not address their concerns sufficiently.

Internal reporting presents certain advantages as they were developed above. Despite these advantages, it, also, presents some disadvantages. An important tension is created between the employee's ability to report internally and his duty of loyalty. ${ }^{74}$ The contradiction lies to the fact that the corporation should encourage internal reporting whereas, at the same time, this reporting will disrupt the trust relationship between the employee and the corporation. It seems strange the fact that the corporation is obliged to encourage reporting which may harm the internal governance and the corporation itself. ${ }^{75}$ This idiomorphic situation creates, additionally, a moral dilemma to the whistle-blower who will hesitate between breaking the corporation's silence in the name of truth or remain loyal and silent to his employer.

Another important alternative step is the promotion of a new model of business education where morality, ethics and values are in the curriculum in order to enhance the sense of the future employees' responsibilities. ${ }^{76}$ Business education should focus on trust, honesty, decency, accountability and fairness in order to foster the idea that compensation is not the only motive in the financial sector. ${ }^{77}$ The employees in that sector should regard whistle-blowing as a duty towards their company and society. ${ }^{78}$ Business school students should be educated in the consequences of wrongdoings in the financial sector and in which way they impact the real economy and society. ${ }^{79}$ Instead of providing financial rewards, the State may opt to design a new model of education that will enhance new core values in the business sector for the common good.

\footnotetext{
${ }^{72}$ Michael Neal, 'Securities Whistleblowing under Dodd-Frank: Neglecting the Power of "Enterprising Privateers" in Favor of the "Slow-Going Public Vessel”" (2012) Lewis \& Clark Law Review, vol. 15:4, 1132. 73 ibid., 1132.

${ }^{74}$ Janet Malek, 'To tell or not to tell ? The ethical dilemma of the would-be whistleblower' (2010) Accountability in Research, vol. 17:3, 115, 123.

75 Patrice Cailleba and Sandra Charreire Petit, 'The whistleblower as the personification of a moral and managerial paradox' (2018) Revue Management, vol. 21, 675, 677.

${ }^{76}$ Hilary J. Allen, 'The Pathologies of Banking Business as Usual' (2015) 17 University of Pennsylvania Journal of Business Law 861, 894.

77 Allen (n 76) 895.

${ }^{78}$ Inger Hoedt-Rasmussen and Dirk Voorhoof, 'Whistleblowing for sustainable democracy' (2018)

Netherlands Quarterly of Human Rights, vol. 36(1) 3-6, 4-5.

${ }^{79}$ Brett McDonnell, 'Don't Panic! Defending Cowardly Interventions Durimg and After a Crisis' (2011) 116

Pennsylvania Student Law Review 1, 13, 27.
} 
Remodeling of business education, with the introduction of more classes on business ethics, occurs, often, when a banking or financial crisis happens. ${ }^{80}$ This demonstrates that business education presents a certain contradiction: on the one hand, promotion of business ethics and consideration of the common good and on the other hand, the employees are required to demonstrate their loyalty and the fact that they should be responsible and free to decide. ${ }^{81}$ Therefore, the employee, especially the one who holds a superior position, is faced with his business education where business ethics have an important position and should be integrated during his working experience and the need for a dedicated and loyal employee in his everyday working life. To that end, education should not only be understood in terms of academic training but broadly. Education should be continued in the working place with special training sessions which will transform the reporting of 'bad' news to 'good' news. ${ }^{82}$ As a result, the corporation itself can invest in education in order to overpass the aforementioned contradiction. ${ }^{83}$

A last alternative solution is an international coordination of the issue by using the financial regulatory networking institutions such as the Basel Committee. ${ }^{84}$ At the moment, the SEC offers significant financial rewards which worried the Congress when enacting the Dodd- Frank Act as there is no international consensus on a meaningful reform of the financial markets. ${ }^{85}$ The U.S. efforts to project their rules to other countries has been opposed by several European Nations. The U.S. Supreme Court held in Morrison v National Australia Bank that antifraud provision of the U.S. securities laws does not apply extraterritorially. ${ }^{86}$ Perhaps, international organisations such as the International Organisation of Securities Commissions (IOSCO) or the FSB (Financial Stability Board) may lead the discussions in order to find a sustainable solution about whistle-blowing in financial markets and more specifically about financial rewards. ${ }^{87}$

Despite the fact that an international solution to financial rewards may an optimal solution, the use of international law may not offer the necessary legal strength such a step will need. The problem lies to the soft law characteristics of international law. ${ }^{88}$ An international law solution will not be a binding one as international law cannot be binding for states. It is certain that, in the financial sector, international legal instruments are respected and followed by many states but they do not have a binding legal nature. ${ }^{89}$ In addition, the international law has an enforcement problem as there will be no authority able

\footnotetext{
80 Patrice Cailleba and Sandra Charreire Petit, 'The whistleblower as the personification of a moral and managerial paradox' (2018) Revue Management, vol. 21, 675, 677.

81 ibid.

82 Michael Davis, 'Avoiding the tragedy of whistleblowing' (1989) Business and Professional Ethics Journal, 10-11.

83 ibid.

${ }^{84}$ Skinner (n 9) 922.

${ }^{85}$ John C. Coffee, Jr., 'Extraterritorial Financial Regulations: Why ET Can’t Come Home' (2014) 99 Cornell Law Review 1259.

86561 U.S. 247 (2010) 265.

87 International Organisation of Securities Commission, $<$ https://www.iosco.org/about/ > and Financial Stability Board, $<\underline{\text { http: //www.fsb.org }>\text {. }}$

${ }^{88}$ Cornelia Manger-Nestler, 'Impacts of International law on the restructuring of the global financial system (2011) 15 Max Planck Yearbook of United Nations 165, 204.

${ }^{89}$ David Zaring, 'Legal obligation in International law and International finance' (2015) 48 Cornell International Law Journal 1, 176.
} 
to control the enforcement of such measure. ${ }^{90}$ If an international legal solution is adopted for financial rewards, its implementation will rely on the good will of states and the need for their international image in the financial industry which may lead to the adoption of that solution.

\section{CONCLUDING REMARKS}

The European countries and the EU have made significant progress on the issue of whistleblowing at the banking and financial sector. ${ }^{91}$ This progress demonstrates a change of culture towards accepting whistle-blowing. Despite this progress, the issue of financial rewards for the whistle-blowers remains controversial for the EU compared to the US practice. Cultural and societal factors in the EU, such as the memories of the Nazi regime or of the Soviet Union, had impeded the acceptance of whistle-blowing which in turn results in an impediment with the issue of financial rewards. The US conception for financial rewards is different as demonstrated.

The financial rewards discussion for the financial markets, and maybe for other sectors, will continue at the EU level in the light of the proposed Directive of the European Commission. The purpose of this paper is to highlight that the enactment of a bounty programme similar to the one of the SEC may not be effective at the EU level at this point. The most important step is to follow the discussions, relating to the proposal for the Directive, and indeed to examine the final version when this is made available. Once the Directive is adopted, then the discussion about financial rewards could reappear as a Directive on the protection of whistle-blowers may change the EU culture on the issue.

The financial rewards have been considered in the light of the US practice and the conclusion is that it may be premature for the EU to ask for bounty programs from the Members States. As a first step, the legislation could be introduced and following a review of its effectiveness and suitability in this context, the issue of financial rewards may be reinforced and introduced by the different Member States or even at the EU level. It is recommended that the alternatives to financial rewards, as discussed, should be put in place with the final aim to reopen the discussion about them once the directive is voted and implemented at the EU level.

\footnotetext{
${ }^{90}$ Jean d'Aspremont, 'The collective security system and the enforcement of international law' in Marc Weller(ed.) The Oxford handbook of the use of force in international law (2015, OUP) 129.

91 There are specific provisions on whistle-blowing resulting from the EU legislation on banking and financial law. See to that extent : art. 23 of the SSM Regulation, art. 36 of the SSM Framework Regulation and the Regulation for prudential requirements for credit institutions and investment firms (575/2013) for the banking sector. For the financial sector see : art. 32 of the Market Abuse Regulation (596/2014) and its Commission Implementing Directive 2015/2392) and art. 96 of the Payment Services Directive (2015/2366).
} 